\title{
Effect of nitrogen and phosphorus additions on a benthic microbial mat from a hypersaline lake
}

\author{
Antonio Camacho' ${ }^{1}$, Rutger de Wit ${ }^{2, *}$ \\ ${ }^{1}$ Department of Microbiology and Ecology, Cavanilles Institute of Biodiversity and Evolutionary Biology, University of \\ Valencia, 46100 Burjassot, Spain \\ ${ }^{2}$ Laboratoire d'Océanographie Biologique, UMR 5805, CNRS and Université Bordeaux 1, 33120 Arcachon, France
}

\begin{abstract}
The effect of the increase in availability of inorganic nutrients (nitrogen and phosphorus) on a benthic microbial mat from the hypersaline Lake Salada de Chiprana (NE Spain) was assayed by nutrient-addition experiments in mesocosms, using $16 \mathrm{~d}$ incubation periods. The upper layer of the mat was dominated by diatoms, whereas the cyanobacterium Microcoleus chthonoplastes and filamentous green bacteria containing Bacteriochlorophyll (Bchl) $d$ dominated deeper layers. The addition of nitrogen alone favoured an increase in total abundance of diatoms with respect to cyanobacteria, although without significant changes in the relative abundance of different diatom genera. Furthermore, this treatment resulted in decreased rates of gross oxygenic photosynthesis. In contrast, phosphorus additions, either alone or supplemented with nitrogen, increased the relative abundance of cyanobacteria with respect to diatoms. No direct effects of the different treatments on green bacteria were observed. The balanced availability of high amounts of both $\mathrm{N}$ and $\mathrm{P}$ supported an increase in biomass of oxygenic phototrophic populations, especially cyanobacteria. This was attributed to a combination of stimulating active growth and decreasing senescence; the latter was reflected by more than 3 -fold increase of the ratio of chl a to phaeophytin $a$. Dinitrogen fixation was measured indirectly as acetylene reduction activity (ARA). ARA rates were low at the start of the experiments and remained low in the $\mathrm{N}$ treatment, while a strong stimulation was found in the control, $\mathrm{P}$ and N+P treatments. Because $M$. chthonoplastes is not capable of fixing dinitrogen, the stimulation of ARA was attributed to nitrogenase activities of heterotrophic bacteria. Our findings are generally in agreement with the resource ratio theory that predicts directional changes of community structure as a consequence of changing resource supply ratios. In addition to the effect of nutrient supply regimes on taxonomic structure of benthic communities, we also observed changes in some of their functional properties. However, application of this theory to sediment systems is not straightforward, because nutrient supply rates depend on the combined effect of mass transfer from the water column to the sediment, internal recycling and geochemical processes (precipitation/ dissolution) in the sediment. Sediment processes are difficult to quantify.
\end{abstract}

KEY WORDS: Microcoleus chthonoplastes · Diatoms · Chloroflexus-type bacteria · Phosphate · Inorganic nitrogen · Gross oxygenic photosynthesis · Bioassay · Resource ratio theory · Lake Salada de Chiprana Resale or republication not permitted without written consent of the publisher

\section{INTRODUCTION}

Phototrophic organisms use light energy to construct new cell material from elementary nutrients such as carbon, nitrogen, and phosphorus. When one of these becomes limiting, its rate of supply will in turn determine their growth rates (Riegman \& Mur 1986). Nutri- ent-addition bioassays, which have been extensively used for studying nutrient limitation in phytoplankton (Elser et al. 1990), can provide valuable information for the understanding of the effects of nutrient enrichment or removal on lakes (Goldman 1978, Sommer 1989).

Microbial mats are laminated microbial communities that form vertically stratified layers of interdependent 
microorganisms on the surface of sediments (Stal et al. 1985). They may include photoautotrophic, chemoautotrophic and heterotrophic microorganisms (Bebout et al. 1987). Microbial mats are found in a variety of habitats, such as intertidal areas (Stal et al. 1985, Van Gemerden et al. 1989, Esteve et al. 1992), hot springs (Castenholz 1976, 1977, Ward et al. 1998) and hypersaline environments (Jørgensen et al. 1986, Giani et al. 1989, Stolz 1990, Caumette et al. 1994), the latter usually dominated by the cyanobacterium Microcoleus chthonoplastes (Des Marais 1995). A few studies (Nilsson et al. 1991, Sundbäck \& Snoeijs 1991, Flothmann \& Werner 1992, Pinckney et al. 1995a, Hillebrand et al. 2000) have dealt with the effect of changes in inorganic nutrient availability on photosynthetic benthic microbial communities in marine and coastal environments, but we are not aware of previous reports of similar studies in hypersaline lakes. Inland hypersaline lakes are, however, particularly prone to accumulate nutrients, because they often occupy the lower parts of endorheic basins. According to the available knowledge, short-term (hours to days) bioassay experiments do not result in significant changes in the growth of benthic phototrophic microorganisms (Paerl et al. 1993, Pinckney et al. 1995b). Instead, it is recommended that a slightly longer time of exposure be used to increase nutrient concentrations ( $>10 \mathrm{~d}$ ) to highlight the effect of nutrient enrichment on the community structure and function (Pinckney et al. 1995a).

In several semi-arid regions of Spain, endorheic lakes are relatively abundant, some of them presenting extensive microbial mats (Guerrero \& De Wit 1992). These lakes are usually characterised by their highly saline waters. The zone of the Middle Ebro River Valley is a semiarid region located in northeastern Spain. Several saline lakes are found in this area, including the only permanent Spanish saline lake, Salada de Chiprana, located in the Monegros region, which exhibits multilayered benthic microbial mats built by the cosmopolitan cyanobacterium Microcoleus chthonoplastes (Vidondo et al. 1993). Many of these inland saline lakes in Spain receive occasional or permanent discharges of nutrient-rich (inorganic nitrogen and phosphorus) waters, which may alter the structure and function of their microbial communities (Guerrero \& De Wit 1992). For lake Chiprana, it has been documented that intensification of agriculture and irrigation enhanced run-off into the lake, particularly in the early 1990s. This resulted in decreasing salinity and eutrophication due to increased $\mathrm{P}$ and $\mathrm{N}$ concentrations in the water column. The initial result was an increase of the Ruppia meadows at the expense of the surface area occupied by microbial mats. However, continuing eutrophication and desalinisation resulted in heavy epiphytic growth on Ruppia. The nutrient input, in concert with a drastic decrease of the population densities of the water column grazer Artemia parthenogenetica, resulted in dense phytoplankton blooms and reduced light penetration. As a result, microbial mats virtually disappeared from the deeper parts of the littoral zone and dramatically changed their compositions in the shallower waters by 1993 (Diaz et al. 1998). This phenomenon gave rise to conservation measurements by the local authorities, who became aware of the negative impact of run-off on the original communities. Currently, runoff from the small watershed is the only surface flux other than rain that feeds the lake, and water column nutrient concentrations (especially phosphorus) have decreased, although not yet to earlier conditions. Since 1995, a particularly dry year in this region, water column transparencies have recovered (Valero-Garces et al. 2000), and we observed the re-establishment of $M$. chthonoplastes microbial mats by September 1996. Recolonisation by microbial mats continued, and by 1999 the extent of microbial mats was similar to that described for the lake in the late 1980s (Vidondo et al. 1993).

Although the study by Diaz et al. (1998) very carefully documented the ecosystem changes in Lake Chiprana during the early 1990s, it is difficult to decipher the direct effect on the microbial mat communities of each of the main changing environmental factors - i.e. decreasing salinity and increasing nutrients - because these factors were partly correlated, and because of the cascading effects in the ecosystem. Therefore, we chose an experimental approach. The aim of the present study was to assess the effect of inorganic nutrients on the structure and function of the photosynthetic community of the benthic microbial mats in Lake Chiprana. Our main hypothesis was that increased nutrient availability (mainly nitrogen and phosphorus) within the lake strongly modifies lacustrine conditions, inducing changes in the community structure and function of microbial mats. According to the resource ratio theory, it is also expected that unbalanced N:P ratios, with respect to the Redfield ratio, will induce taxonomic shifts in the community structure (e.g. Tilman 1982).

\section{MATERIALS AND METHODS}

Sampling site. La Salada de Chiprana is a hypersaline lake located in the Middle Ebro River Valley in the north-east of the Iberian Peninsula $\left(41^{\circ} 14^{\prime} \mathrm{N}\right.$, $0^{\circ} 10^{\prime} \mathrm{W}$ ) at $150 \mathrm{~m}$ above sea level, in a semi-arid region (330 $\mathrm{mm}$ annual average rainfall and $16^{\circ} \mathrm{C}$ mean temperature, Vidondo et al. 1993). This is the only deep permanent saline lake located in the Iberian Peninsula 
(Guerrero et al. 1991), with a surface of 31 ha and maximum depth of $5.6 \mathrm{~m}$. In May 1999, when sampling was performed, $\mathrm{pH}$ was 8.27 and conductivity was $59.8 \mathrm{mS}$ $\mathrm{cm}^{-1}$. According to Diaz et al. (1998), average salinity varied between 30 and $73 \mathrm{~g} \mathrm{l}^{-1}$ from 1990 to 1996. In October 2000 and May 2001, the salinity was $78 \mathrm{~g} \mathrm{l}^{-1}$ and was dominated by $\mathrm{Na}^{+}$(ca. $500 \mathrm{mM}$ ), $\mathrm{Mg}^{2+}$ (about $350 \mathrm{mM}$ ), $\mathrm{SO}_{4}{ }^{2-}$ (about $450 \mathrm{mM}$ ) and $\mathrm{Cl}^{-}$(about $300 \mathrm{mM}$ ) (Jonkers et al. 2003). The lake is often stratified due to a salinity gradient, and anoxia occurs in deep layers during certain periods (Guerrero et al. 1991, Diaz et al. 1998). Stratification is most common during the winter period especially after periods of rainfall. However, over longer time periods the alternation between holomixis and stratified periods is extremely variable depending on the metereological conditions. After a period of eutrophication and desalinisation in the early 1990s, Microcoleus chthonoplastes mats virtually disappeared (see 'Introduction' and Diaz et al. 1998). M. chthonoplastes recolonised the lake after 1996 and occupied large surface areas at shallow water depths during sampling in spring 1999.

Experimental design. Sediments covered with $\mathrm{Mi}$ crocoleus chthonoplastes mats in Lake Salada de Chiprana were sampled on 16 May 1999 in the zone of maximal development of these mats, a shallow area located in the northern part of the lake. Up to 16 samples $\left(250 \mathrm{~cm}^{2}, 10 \mathrm{~cm}\right.$ depth) were excised and placed in separate plastic containers. Each sample was cut to perfectly fit with the walls of the plastic container. Samples were refrigerated, brought to the laboratory and randomly positioned in a fiberglass pool. Water, at a temperature of ca. $20^{\circ} \mathrm{C}$, was continuously circulating in the bottom of the pool to avoid excessive heating of the samples and to maintain temperature close to natural conditions at the time of sampling $\left(22^{\circ} \mathrm{C}\right)$. The pool was placed in a greenhouse and thus the light regime was approximately the same as in natural conditions.

A continuous flow $\left(10 \mathrm{ml} \mathrm{h}^{-1}\right)$ of sterile artificial lake water was supplied by a 16-channel peristaltic pump to replicate samples for $16 \mathrm{~d}$. For practical reasons, we prepared artificial lake water with Arcachon Bay water ( $30 \%$ salinity) filtered through GF/F glass fibre filters, which was sterilised and supplied with $50 \mathrm{~g}$ of $\mathrm{MgSO}_{4} \cdot 7 \mathrm{H}_{2} \mathrm{O} \mathrm{l}^{-1}\left(=200 \mathrm{mM}\right.$ of $\mathrm{Mg}^{2+}$ and $\left.\mathrm{SO}_{4}{ }^{2-}\right)$, to mimic the ionic composition of the lake water. Arcachon Bay is a coastal lagoon, and concentrations of silicates during the study period were 12 to $20 \mu \mathrm{M}$. The silicate concentration in Lake Chiprana water (determined on a filtered sample) was $29.8 \mu \mathrm{M}$ (measured by colorimetry according to Aminot \& Chaussepied 1983). Hence, silicate concentrations in the lake were higher than in the artificial lake water used, and this was also the case for $\mathrm{Mg}^{2+}$ and $\mathrm{SO}_{4}{ }^{2-}$. The dilution rate of the water column overlying the sediment samples was approximately $0.02 \mathrm{~h}^{-1}$. Four different conditions were assayed using the artificial lake water subjected to the following treatments: (1) C: 'control', without nutrient additions; (2) $\mathrm{N}$ : amended with $\mathrm{NH}_{4} \mathrm{NO}_{3}$, final concentration $400 \mu \mathrm{mol} \mathrm{N} \mathrm{^{-1 }}$; (3) P: amended with $\mathrm{NaH}_{2} \mathrm{PO}_{4}$, final concentration $25 \mu \mathrm{mol} \mathrm{P} \mathrm{l}^{-1}$; and (4) N+P: amended with $\mathrm{NH}_{4} \mathrm{NO}_{3}$, final concentration $400 \mu \mathrm{mol}$ $\mathrm{N} \mathrm{l}^{-1}$, and $\mathrm{NaH}_{2} \mathrm{PO}_{4}$, final concentration $25 \mu \mathrm{mol} \mathrm{P} \mathrm{l}{ }^{-1}$. According to the Redfield ratio, the N+P additions maintained a N:P molar ratio of 16 , which is optimal for benthic microalgae (Hillebrand \& Sommer 1999). Four replicates were assayed for each of the treatments. $\mathrm{N}$ and $\mathrm{P}$ additions mimicked those concentrations found in the lake during the period in which agriculture runoff entered the lake (Diaz et al. 1998). $\mathrm{pH}$ after nutrient additions was 8.3, almost the same as in the lake at the time of sampling. Water was carefully mixed and aerated by slow air bubbling in the corner of each plastic container.

The effect of these nutrients on the community structure and function was determined in each of the 4 replicates for each condition assayed after $16 \mathrm{~d}$ incubation, since previous studies (e.g. Nilsson et al. 1991, Pinckney et al. 1995a) suggested that relatively longterm incubations $(>10 \mathrm{~d})$ are necessary to detect changes within the phototrophic community of benthic microbial mats. Changes in the abundance of the different photosynthetic microorganisms of the mat were studied by means of the chemotaxonomy of taxon-specific photosynthetic pigments (Pinckney et al. 1995a), which are relatively conservative with respect to photoacclimation (Rowan 1989). Within diatoms, we studied the changes in the relative percentage of the different genera by microscopic determinations. Moreover, the effect of nutrient addition on photosynthetic activity, $\mathrm{N}_{2}$ fixation (acetylene reduction), total organic carbon, total nitrogen and total phosphorus accumulation, as well as the percent of organic matter in the sediment, was studied.

Pigment analyses. Photosynthetic pigments were determined by HPLC. A sediment core of $400 \mathrm{~mm}^{2}$ surface and $5 \mathrm{~mm}$ depth was obtained from each of the 16 samples after the $16 \mathrm{~d}$ incubation period. Samples were lyophilised and the dry weight was then determined. Pigments were extracted with acetone using 3 successive extractions of 1,6 and $12 \mathrm{~h}$, respectively, after sonication. The 3 extracts were pooled together and methylated with diazomethane. The extracts were then filtered, and the acetone was evaporated by vacuum. Pigments were redissolved in a solvent mixture of $50 \%$ methanol, $45 \%$ acetonitrile and $5 \% \mathrm{H}_{2} \mathrm{O}$. The samples thus prepared were injected on the HPLC system (Thermo-Finnigan) and the peaks were compared with standards for calculation of pigment concentra- 
tions following the procedure described by Buffan Dubau et al. (2001). The abundance of specific pigments was used to evaluate the abundance of different major taxa of the phototrophic microorganisms. Cyanobacterial abundance was measured by the concentrations of myxoxanthophyll, fucoxanthin was used to determine the abundance of diatoms, and the abundance of filamentous green bacteria was quantified by bacteriochlorophyll $d(\mathrm{Bchl} d)$ concentration. Chl a content was used to evaluate the total abundance of oxygenic phototrophs. Health status of the populations of oxygenic phototrophs was assayed using the ratio between chl a and its major degradation product (Pheophytin a). The relative abundance of diatoms versus cyanobacteria was obtained from the fucoxanthin/myxoxanthophyll molar ratio.

$\mathbf{N}_{2}$ fixation (acetylene reduction). $\mathrm{N}_{2}$ fixation was indirectly measured twice in the 16 samples by the acetylene reduction assay. The first measurements were performed $24 \mathrm{~h}$ after starting nutrient additions and the second measurements at the end of the bioassay (after 16 d). For each of the samples, a bell jar was inserted in the sediment, then $10 \mathrm{ml}$ of pure acetylene was injected and allowed to stand for $6 \mathrm{~h}$ under the natural light regime. After this time, the concentration of acetylene and ethylene in the gas phase was determined by gas chromatography, and rates of acetylene reduction were calculated (Stal 1988).

Oxygenic photosynthesis. To compare photosynthetic potential of the mats subjected to different conditions, we choose to use $500 \mu \mathrm{mol}$ photons $\mathrm{m}^{-2} \mathrm{~s}^{-1}$ incident irradiance as standard conditions. Similar light intensities were frequently observed in the greenhouse, but large variations occurred due to natural changing light climate. In the field, light intensities change dramatically during a diurnal cycle, and the effects of in situ light intensities on oxygen and photosynthesis profiles in the natural mats have been described elsewhere (Jonkers et al. 2003). Oxygen concentrations were measured with a polarographic oxygen microelectrode (MasCom) while mat samples were exposed to cool-white illumination at $500 \mu \mathrm{mol}$ photons $\mathrm{m}^{-2} \mathrm{~s}^{-1}$. Gross oxygenic photosynthesis was determined at depth intervals of $200 \mu \mathrm{m}$ through the sediment by measuring the decrease in oxygen concentration (the slope of the curve) after shifting the samples from light to dark conditions for $4 \mathrm{~s}$ (Revsbech \& Jørgensen 1983). These rates were corrected for sediment porosity and integrated over the sediment column to calculate areal rates. Two profiles of photosynthesis were made at different spots in each of the 4 replicates for each of the 4 different conditions assayed.

Chemical analyses of the sediment. Total organic carbon (TOC), total nitrogen (TN), total phosphorus
(TP) and percent organic mater were also determined in sediment cores of $400 \mathrm{~mm}^{2}$ surface and $5 \mathrm{~mm}$ depth at the end of the experiment. TOC and TN were determined with a C:N analyser (Thermo-Finnigan) after acid treatment. TP was determined after persulphaticacid hydrolysis at $135^{\circ} \mathrm{C}$ for $2 \mathrm{~h}$, then orthophosphate was measured with the phosphomolybdic acidascorbic acid method. Percentage of ash-free organic matter was determined after ignition of dry samples at $460^{\circ} \mathrm{C}$, then the weight loss was compared with the previous weight.

Relative percentage of diatom genera. Samples of the above-described cores were homogenised with a tissue grinder, brought to a final volume of $100 \mathrm{ml}$, and fixed with $4 \%$ buffered formaldehyde. Next, a small subsample $(250 \mu \mathrm{l})$ of well-mixed homogenate of each of the 16 samples was diluted to a final volume of $50 \mathrm{ml}$ with saline solution and counted by the Utermöhl (1958) sedimentation method. Diatoms were assigned to genera according to Germain (1981) and Krammer \& Lange-Bertalot (1986, 1988, 1991a,b). The percentage of each diatom genera with respect to the entire diatom population was calculated.

Statistics. One-way ANOVA was used to compare the results of the different conditions assayed for each of the parameters determined. Prior to using a parametric ANOVA, we performed a Levene test for variance homogeneity and a posteriori multiple comparisons of the means were made using the Duncan test. Some of the parameters (all except photosynthetic activity, TOC and TN) were also determined before incubation for at least 1 of the different replicates for each treatment; no significant differences $(p<0.05)$ among replicates were detected. Differences at the end of the experiment were thus attributed to treatment effects (control vs nutrient additions).

\section{RESULTS}

\section{Description of the microbial mat}

Compact microbial mats developed in the shallow part of Lake Salada de Chiprana. Diatoms were the most abundant photosynthetic microorganisms in the upper part of the mat ( 0 to $1 \mathrm{~mm}$ ). The dominant diatoms in the mat corresponded to 4 genera, mainly Fragilaria, Cymbella, Cocconeis and Navicula, although Amphora spp. were also present at lower densities. Whereas diatoms dominated surface layers, deeper parts of the mat were dominated by both the cyanobacterium Microcoleus chthonoplastes, which was also relatively abundant in the mat surface, and by filamentous green phototrophic bacteria, which contain Bchl $d$ as the major chlorophyll pigment (Qy 


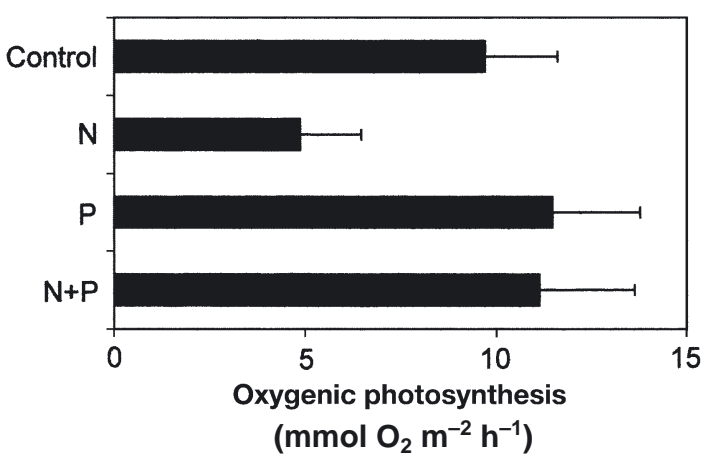

Fig. 1. Gross oxygenic photosynthesis measured at $500 \mu \mathrm{mol}$ photons $\mathrm{m}^{-2} \mathrm{~s}^{-1}$ incident irradiance after $16 \mathrm{~d}$ of incubation. Four different conditions were assayed: control: without nutrient additions; N: supplied with $400 \mu \mathrm{mol} \mathrm{N}{ }^{-1}$; P: supplied with $25 \mu \mathrm{mol} \mathrm{P} \mathrm{l}{ }^{-1}$; and $\mathrm{N}+\mathrm{P}$ : supplied $400 \mu \mathrm{mol} \mathrm{N} \mathrm{l^{-1 }}$ and $25 \mu \mathrm{mol} \mathrm{P} \mathrm{^{-1 }}$. Mean values +SD for the 4 replicates are plotted

absorption maximum on-line in HPLC was $653 \pm 1 \mathrm{~nm}$ ). Most likely, these filamentous green bacteria are Chloroflexus relatives, a phylogenetic cluster that has been described recently by Nübel et al. (2001). This association of mesophilic Microcoleus and Chloroflexus-type microorganisms has also been found in other microbial mats (Stolz 1990, Nübel et al. 2001). In a slightly different site in the lake, Chloroflexus-type microorganisms were also observed in other periods in association with M. chthonoplastes, but these were found to possess bacteriochlorophyll c (Qy absorption maximum on-line in HPLC was $663 \pm 1 \mathrm{~nm}$ ) as the major chlorophyll pigment (Jonkers et al. 2003).

A complete segregation of the phototrophic communities was not found within the Chiprana mat, since diatoms were also present below the upper layer and bundles of Microcoleus chthonoplastes were also found in the upper part of the mat. This could be caused by the vertical movements of these microorganisms (Whale \& Walsby 1984, García-Pichel et al. 1994, Sundbäck et al. 1996). Abundance of benthic fauna was very low and restricted to the occasional presence of nematodes and unidentified protozoa. Hence, the structural and functional integrity of the mat was maintained because bioturbation and predation by meiofauna were very low (Fenchel 1998).

\section{Oxygenic photosynthesis}

Fig. 1 shows the integrated gross oxygenic photosynthesis in the different treatments. Oxygenic photosynthetic activity was significantly different $(p=0.0157)$ among the conditions assayed, but only the $\mathrm{N}$ treatment exhibited significantly lower gross photosynthetic activity when compared with the other treat- ments $(p=0.0045$ for $P$, and $p=0.0016$ for $N+P)$. Although phosphorus additions (either $\mathrm{P}$ or $\mathrm{N}+\mathrm{P}$ ) resulted in higher gross photosynthesis rates, the values were not significantly different from controls $(\mathrm{p}=0.4008$ for $\mathrm{P}$, and $\mathrm{p}=0.7527$ for $\mathrm{N}+\mathrm{P}$ ).

\section{$\mathbf{N}_{2}$ fixation (acetylene reduction)}

After $24 \mathrm{~h}$ of incubation with nutrients, differences in acetylene reduction were not significant $(p=0.2354)$ among the treatments (Fig. 2A). However, after $16 \mathrm{~d}$ (Fig. 2B), the differences were significant $(p=0.0030)$. Very low acetylene reduction was detected in the $\mathrm{N}$ treatment, in contrast with increased activity in the rest of the treatments $(p=0.0039)$. Acetylene reduction activity (ARA), although at a lower rate than in the $P$ treatment and in the control, was also stimulated in the $\mathrm{N}+\mathrm{P}$ treatment with respect to initial rates. In the $36 \mathrm{~h}$ incubation experiments, active acetylene reduction was calculated both during the light and the dark periods (data not shown), and ARA rates were only slightly higher (ca. $10 \%$ ) in the dark.
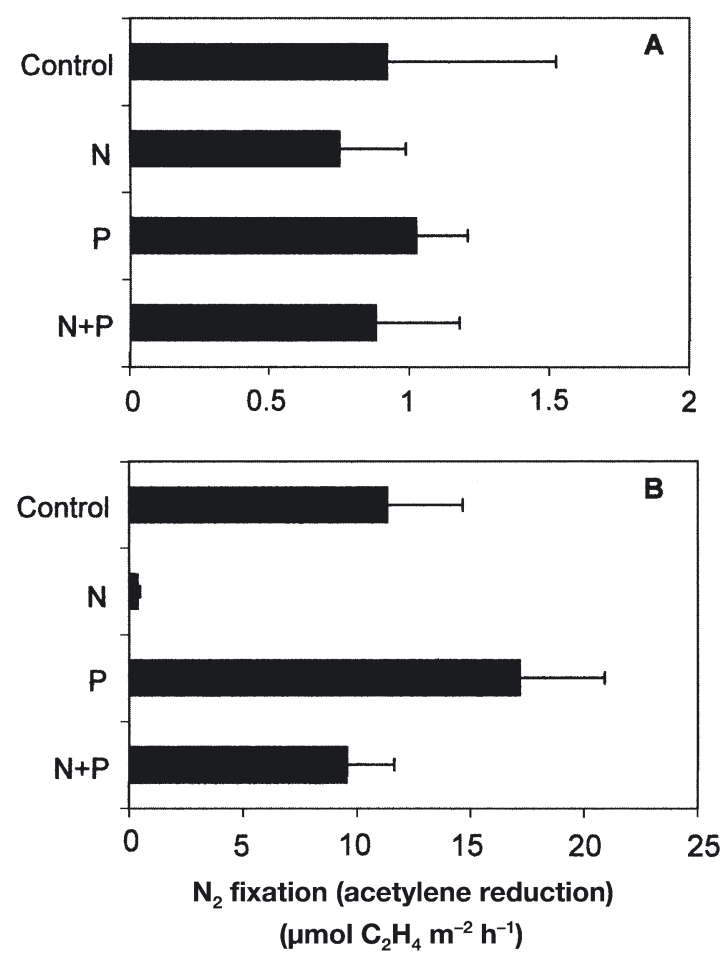

Fig. 2. Nitrogenase activity (measured as acetylene reduction rates) in the different treatments after (A) $1 \mathrm{~d}$ of incubation and (B) $16 \mathrm{~d}$ of incubation. Four different conditions were assayed: Control: without nutrient additions; N: supplied with $400 \mu \mathrm{mol} \mathrm{N} \mathrm{^{-1 }}$; P: supplied with $25 \mu \mathrm{mol} \mathrm{P} \mathrm{l}^{-1}$; N+P: supplied

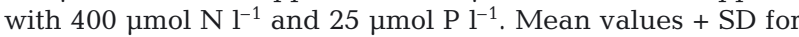
the 4 replicates are plotted. Note the difference in scales 


\section{Chemistry of the sediments}

TOC, TN, TP, percentage organic matter, and the TN:TP and TOC:TN ratios of the top $0.5 \mathrm{~cm}$ sediment in the different treatments are shown in Fig. 3. Organic matter was 40 to $45 \%$ of the dry weight on average, and slightly higher percentages of organic matter were found in the N+P treatment, but without statistical significance $(p=0.5266)$. The TOC values were 150 to 170 mg C g ${ }^{-1}$ of sediment without significant differences among treatments. TN in the $\mathrm{N}$ treatment was $20 \mathrm{mg} \mathrm{N}$ $\mathrm{g}^{-1}$ of sediment on average, while for the other treatments the values were 17 to $18 \mathrm{mg} \mathrm{N} \mathrm{g}^{-1}$ on average; however, these differences were not statistically significant ( $p=0.9210)$. Also, while total phosphorus concentration in the sediment was higher in the P treatment, these differences were not significant $(\mathrm{p}=$ 0.1298). The average TOC:TN molar ratio was $9.5 \mathrm{~mol}$
$\mathrm{C}$ per mol $\mathrm{N}$ in the $\mathrm{N}$ treatment and $10.5 \mathrm{~mol} \mathrm{C}$ per mol $\mathrm{N}$ in the other treatments, but the differences were also not significant $(\mathrm{p}=0.2911)$. Comparing all treatments, the average TN:TP ratio showed significant treatment effects $(\mathrm{p}=0.0450)$, and the TN:TP molar ratio ranged from $2.9 \mathrm{~mol} \mathrm{~N}$ per mol P (P treatment) to $4.7 \mathrm{~mol} \mathrm{~N}$ per mol $\mathrm{P}$ in the $\mathrm{N}$ treatment.

\section{Changes in the composition of the phototrophic community}

HPLC analyses of specific photosynthetic pigments allowed us to study the response of the 3 taxa of phototrophic microorganisms (cyanobacteria, diatoms and green filamentous bacteria) to nutrient enrichment, and the effect of community changes on each individual taxon (Figs. 4 \& 5). Chl a concentration was much
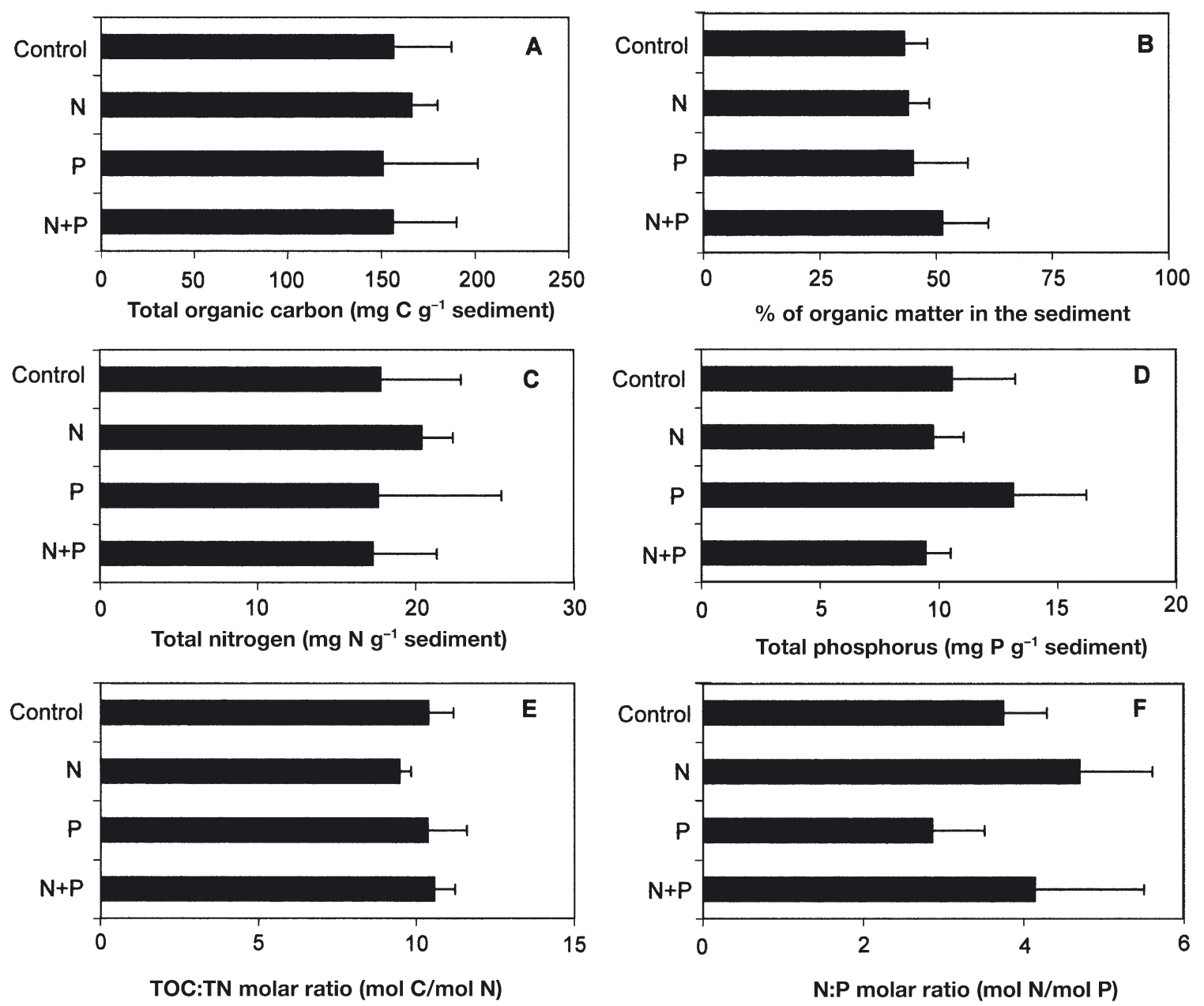

Fig. 3. Elemental contents and organic matter contents of the top $5 \mathrm{~mm}$ of the sediment in the different treatments (Control: with-

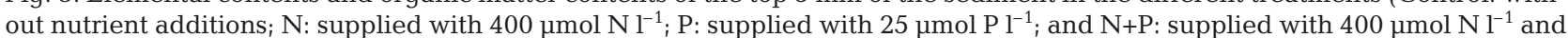

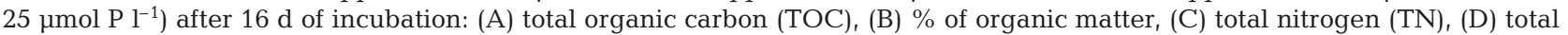
phosphorus (TP), (E) TOC:TN molar ratio, and (F) TN:TP molar ratio. Mean values + SD for the 4 replicates are plotted 

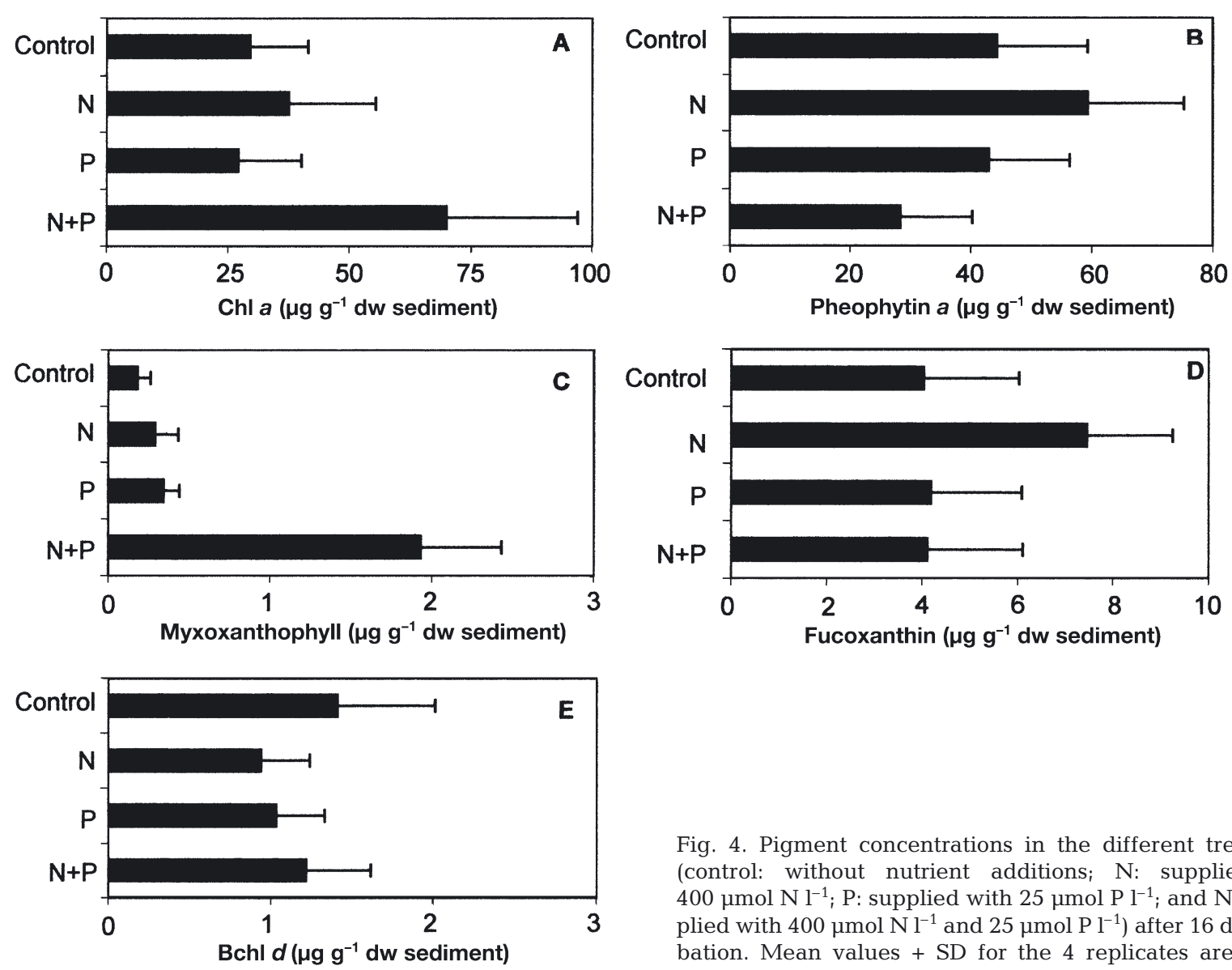

Fig. 4. Pigment concentrations in the different treatments (control: without nutrient additions; $\mathrm{N}$ : supplied with

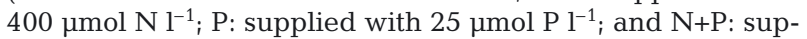
plied with $400 \mu \mathrm{mol} \mathrm{N}{ }^{-1}$ and $25 \mu \mathrm{mol} \mathrm{P} \mathrm{l}^{-1}$ ) after $16 \mathrm{~d}$ of incubation. Mean values $+\mathrm{SD}$ for the 4 replicates are plotted

higher in the N+P treatment (Fig. 4) and differed significantly from all other treatments $(p=0.023)$. No statistical differences were found between the control and the single additions of a nutrient $(\mathrm{p}=0.927$ and $\mathrm{p}=$ 0.998 for $\mathrm{N}$ and $\mathrm{P}$, respectively). Pheophytin a concentrations (Fig. 4) were lower in the N+P treatment, and significantly different from the $N$ treatment ( $p=0.040)$; the $\mathrm{N}+\mathrm{P}$ treatment also achieved the highest $\mathrm{chl}$ a:pheophytin a ratios (Fig. 5), with significant differences with the rest of the treatments $(p=0.012)$, indicating that high nutrient levels promote net growth and decrease senescence of oxygenic phototrophs in the mat. Myxoxanthophyll was used as specific marker of cyanobacterial abundance in the Chiprana mat (Fig. 4), and showed significantly higher values in the $N+P$ treatment $(p=0.015)$. $P$ additions yielded only slightly elevated myxoxanthophyll concentrations, but did not differ significantly from control and nitrogen treatments ( $p=0.904$ and 0.931, respectively). Bchl $d$ concentrations were quite similar among the different treatments ( $p=0.9812)$ and apparently were not influenced by nutrient addition (Fig. 4). Fucoxanthin, a specific pigment of diatoms within the microbial community of the Chiprana microbial mat, showed higher

(although not significantly, $\mathrm{p}=0.075$ ) values in the nitrogen $(\mathrm{N})$ treatment compared to other treatments, but their concentrations in the $\mathrm{N}+\mathrm{P}$ treatment did not differ with those in the control and P conditions (Fig. 4). Fucoxantin:myxoxanthophyll ratios (Fig. 5) were significantly higher in the $\mathrm{N}$ treatments than in those including phosphorus additions $(\mathrm{p}=0.047$ for $\mathrm{P}$ and $\mathrm{p}=$ 0.0001 for $\mathrm{N}+\mathrm{P}$ ), indicating that the single addition of nitrogen favoured growth of diatoms with respect to cyanobacteria, while phosphorus additions (either alone or combined with nitrogen) promoted the relative increase of cyanobacteria with respect to diatoms.

Microscopic counts showed that the relative percentage of the different diatom genera among the treatments at the end of the bioassay did not change significantly (Table 1).

\section{DISCUSSION}

Experimental additions of inorganic nutrients resulted in several changes in the structure and function of the microbial mat community. Pigment chemotaxonomy has proven to be a useful tool for detecting 

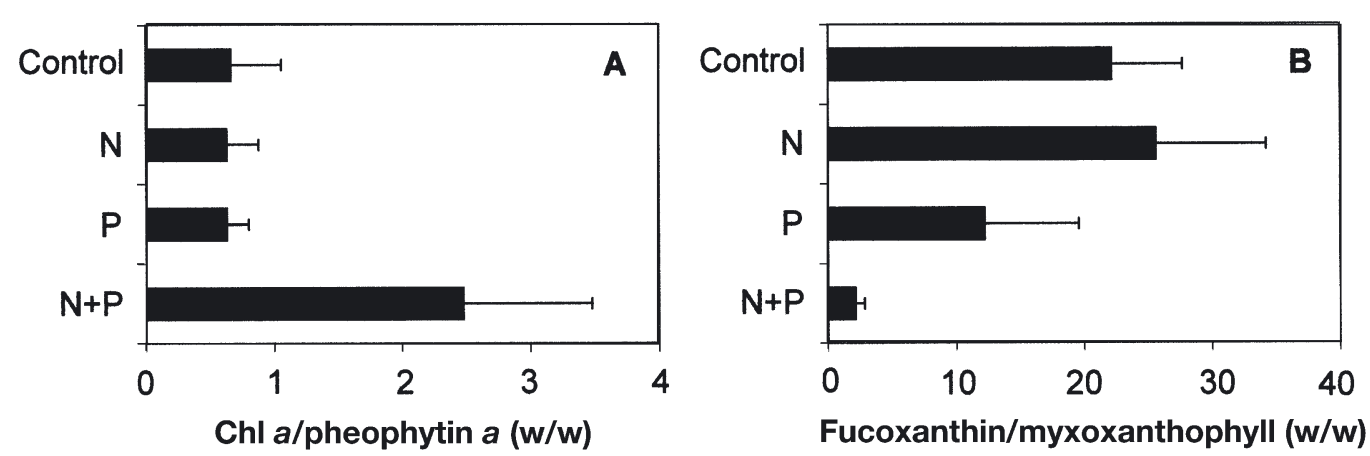

Fig. 5. Pigment ratios (weight:weight) in the different treatments (control: without nutrient additions; N: supplied with $400 \mu \mathrm{mol}$

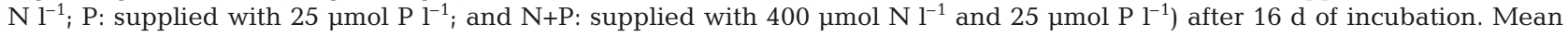
values $+\mathrm{SD}$ for the 4 replicates are plotted

changes in the abundance of the different phototrophic microorganisms (e.g. Pinckney et al. 1995a). Chl a concentration can be used to jointly estimate the development of oxygenic phototrophs; it was much higher in the $\mathrm{N}+\mathrm{P}$ treatment, showing that high but balanced nutrient concentrations stimulate growth of oxygenic phototrophs in the mat. Although higher chl a concentrations were observed in the $\mathrm{N}$ treatment than in the control and $\mathrm{P}$ treatments, these differences were not statistically significant.

\section{Relative abundance of diatoms and cyanobacteria}

The concentrations of the cyanobacterial pigment myxoxanthophyll increased dramatically when both nitrogen and phosphorus were added simultaneously (see Fig. 4C, N+P treatment). But single nutrient additions, either nitrogen or phosphorus alone, did not significantly stimulate accumulation of cyanobacteria in the mat as reflected by myxoxanthophyll concentrations. This shows that the cyanobacterial population of the Chiprana mat experiences a relatively low availability of both nitrogen and phosphorus. Although one of these nutrients could be limiting in some circumstances, small changes in nutrient availability would

Table 1. Relative percentage of the different diatom genera after $16 \mathrm{~d}$ incubation in the different treatments. Four different conditions were assayed: control:

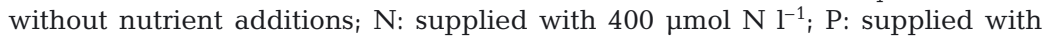

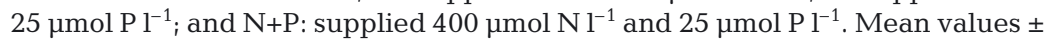
$\mathrm{SD}$ and $\mathrm{p}$-values obtained in ANOVAs are shown

\begin{tabular}{|lcccrc|}
\hline & Control & $\mathrm{N}$ & $\mathrm{P}$ & $\mathrm{N}+\mathrm{P}$ & $\mathrm{p}$-values \\
\hline Fragilaria spp. & $72.4 \pm 10.6$ & $63.7 \pm 9.3$ & $66.7 \pm 11.2$ & $73.3 \pm 5.8$ & 0.506 \\
Cymbella spp. & $12.9 \pm 1.6$ & $19.1 \pm 8.0$ & $17.7 \pm 8.9$ & $12.4 \pm 2.6$ & 0.341 \\
Cocconeis spp. & $9.9 \pm 7.1$ & $7.9 \pm 5.3$ & $6.8 \pm 4.0$ & $9.3 \pm 4.9$ & 0.854 \\
Navicula spp. & $4.5 \pm 1.7$ & $8.7 \pm 4.8$ & $8.3 \pm 3.8$ & $4.4 \pm 1.4$ & 0.266 \\
Amphora spp. & $0.2 \pm 0.2$ & $0.6 \pm 0.5$ & $0.5 \pm 0.4$ & $0.5 \pm 0.4$ & 0.704 \\
\hline
\end{tabular}

then induce a change in nutrient limitation. Accordingly, only the simultaneous increase in the availability of both nutrients can meet the requirements of the cyanobacterial population, since the single increase in the availability of a nutrient would quickly induce limitation by the other.

The stimulation of diatoms in the $\mathrm{N}$ treatment is apparent by their specific accessory pigment (fucoxanthin), which exhibited higher values in the $\mathrm{N}$ treatment, whereas its concentration in the $\mathrm{N}+\mathrm{P}$ treatment was almost equal to the control and $P$ treatments. However, due to large spatial variability within treatments, this was not significant (ANOVA, $\mathrm{p}=0.075$ ). Therefore, we considered the ratio of fucoxanthin:myxoxanthophyll, which showed that the addition of nitrogen favoured growth of diatoms with respect to cyanobacteria. In contrast, addition of phosphorus promoted the relative increase of cyanobacteria with respect to diatoms, although when nitrogen and phosphorus were added simultaneously the increased growth of cyanobacteria drove this ratio to still lower values, showing further increase in cyanobacterial dominance. Thus, the relative availability of $\mathrm{N}$ and $\mathrm{P}$ in conjunction with the differential response of cyanobacteria and diatoms to nutrient availability were responsible for the new community structure found after nutrient additions. This indicates that growth of diatoms in the mat may be limited mainly by nitrogen, but the simultaneous increase in nitrogen and phosphorus availability $(\mathrm{N}+\mathrm{P})$ may also preferentially stimulate cyanobacterial growth and increase competition for other resources (e.g. light), resulting in lower diatom abundance. In fact, all treatments with phosphorus additions visually showed a higher cyanobacterial presence on the surface of the mat. 
We thought that it was not so relevant to study the effect of water column silicate concentrations on the competition between diatoms and cyanobacteria in these microbial mats, because these sediment ecosystems have entrapped high quantities of silicium-rich clay and loam particles. Silicate can thus be provided to microbiota by superficial dissolution of these particles, and sediments are therefore an important source of silicates, as was clearly suggested by earlier experimental observations in marine benthic systems (Nilson et al. 1991, Sundbäck \& Snoeijs 1991). Another study has shown that even for diatom-dominated benthic communities on hard substrates, silica additions had only a minor effect compared to $\mathrm{N}$ or $\mathrm{P}$ additions (Hillebrand \& Sommer 2000). The artificial lake water we used contained less silicate (i.e. 12 to $20 \mu \mathrm{M}$ ) than the lake water on the day of sampling $(29.8 \mu \mathrm{M})$. Recently (September 2002), we observed a very high dissolved silicate concentration of $74 \mu \mathrm{M}$ in Lake Chiprana water. Thus, in the lake, silicate concentrations seem sufficient for abundant diatom growth. In the experimental setup, although unlikely, we cannot exclude that we have limited diatom growth with respect to natural conditions in the lake by potentially reducing mass transfer from the water column to the sediment. The relative importance of mass transfer from the water column to the sediment, and of dissolution of sediment particles for silicate availability to diatoms, deserves further study.

Other authors have studied the effect of enrichment in nitrogen and phosphorus availability on phototrophic microorganisms. Fong et al. (1993) reported that phosphorus addition favoured the development of benthic cyanobacterial mats with respect to other phototrophs. Tilman et al. (1986) showed that planktonic diatoms out-compete cyanobacteria for phosphorus, and are thus favoured by nitrogen additions. Hillebrand \& Sommer (1997, 2000) and Zimba (1998) demonstrated nitrogen limitation in experiments with diatoms growing on solid substrates. In bioassay experiments with periphyton, Marks \& Lowe (1993) observed that nitrogen additions yielded higher growth of diatoms while cyanobacterial growth was stimulated by phosphorus enrichment. In all these cases, diatoms were favoured by high N:P ratios with respect to cyanobacteria. Cyanobacteria are thought to be superior competitors for nitrogen (Tilman et al. 1986) and are favoured by phosphorus additions, which induce nitrogen limitation. Thus, we observed the same pattern in benthic microbial mats where these microorganisms co-occur. Pinckney et al. (1995a) also found an increase in the biomass of diatoms in a nutrient addition bioassay when nitrogen was added, although in this case enhanced diatom growth was also found when nitrogen was supplied with phosphorus, while cyanobacteria were favoured when phosphorus was added alone. Among all treatments tested in our experiments, we did not observe significant shifts among the diatom genera (Table 1). This is surprising because Sundbäck \& Snoeijs (1991) clearly observed that smaller sized diatom genera like Nitzschia and Amphora were favoured when marine benthic systems were fertilised with $\mathrm{N}$ and $\mathrm{P}$.

\section{Resource ratio theory applied to benthic systems}

Tilman's (1982) theory of resource competition, whose applicability has been clearly demonstrated for plankton, provides a mechanistic explication of how resource-supply ratios competitively regulate microbial community structure (Smith 1993). Interspecific variability of specific resource-uptake ratios and of net-zero growth isoclines allow stable coexistence of species, each limited to a different extent by different substrates. Hence, one of the most important predictions of the resource ratio theory for microbial communities is that a directional change in resource supply ratios for 2 or more species competing for those resources should result in a directional shift in their competitive dominance. In benthic microbial mats, inorganic nutrients are supplied by mass transfer from the water column across the sediment surface, and by internal recycling of nutrients due to remineralisation. $\mathrm{N}_{2}$ fixation may represent an additional process for nitrogen acquisition in the mat. By changing the nutrient concentrations in the overlying water column, we modified the mass transfer (molecular diffusion) of nutrients from the water column into the sediment, which, in conjunction with sedimentary remineralisation, changed the relative abundance of potentially limiting nutrients (N:P ratios). This controlled the relative success of the different phototrophic assemblages. Directional changes caused by nutrient addition are thus reflected in a directional shift in the competitive dominance of diatoms and cyanobacteria.

The application of resource ratio theory to sediment systems is therefore not straightforward, because nutrient supply rates depend on the combined effect of mass transfer from the water column to the sediment, internal recycling and geochemical processes (precipitation/dissolution) in the sediment. Elemental analyses of the top $5 \mathrm{~mm}$ of the sediment, which includes the living mat, may give some hint about the recycling of inorganic nutrients from organic matter. The sediment organic matter contents were as high as 40 to $50 \%$ (TOC values were 150 to $170 \mathrm{mg} \mathrm{g}^{-1}$ ), the ratio of TOC:TN was 9.5 (mol C per mol N) in the $\mathrm{N}$ treatment and slightly higher $(10.5 \mathrm{~mol} \mathrm{C}$ per mol $\mathrm{N})$ in the other treatments, and these variables did not differ signifi- 
cantly among treatments. The low molar TN:TP ratios of 3.5 to $4.5 \mathrm{~mol} \mathrm{~N}$ per mol P suggest that sufficient phosphate is present in the sediment with respect to nitrogen. However, a large fraction of the phosphate is often bound to calcium as hydroxy and fluoride apatites, which are less available for uptake by microorganisms. Therefore, a more detailed phosphate fractionation study is required to estimate phosphate bioavailability in the sediment. The high background TP content made it impossible to detect any accumulation in the sediment during $\mathrm{P}$ and $\mathrm{N}+\mathrm{P}$ treatments. In contrast, the lower (although not statistically significant) TOC:TN ratio observed in the $\mathrm{N}$ treatment shows an effect of higher $\mathrm{N}$ accumulation in the $\mathrm{N}$ treatment that is confirmed by the statistically significant higher TN:TP ratio.

\section{$\mathbf{N}_{2}$ fixation}

$\mathrm{N}_{2}$ fixation (acetylene reduction) rates were very low at the beginning of the nutrient-addition experiment. This activity remained very low in the $\mathrm{N}$ treatment after the $16 \mathrm{~d}$ incubation period, but increased significantly in the rest of the treatments, including the control. The increase found in the control shows that the increase in dinitrogen fixation was not a direct effect of nutrient addition. On the contrary, the lack of this increase in the $\mathrm{N}$ treatment indicates that increased $\mathrm{N}$ availability maintained $\mathrm{C}: \mathrm{N}$ ratios at levels that would maintain $\mathrm{N}_{2}$ fixation at very low rates. When nitrogen addition to the Chiprana mat was supplemented with phosphorus, enhanced dinitrogen fixation was also found in parallel with an increase of the TOC:N ratio. In contrast, similar experiments performed in intertidal microbial mats showed an inhibition of nitrogenase activity by nitrogen additions, either alone or combined with phosphorus. In these mats, cyanobacteria apparently overcome nitrogen limitation by $\mathrm{N}_{2}$ fixation (Pinckney et al. 1995a). This response was also observed in mats of Oscillatoria sp., where phosphate fertilisation resulted in strongly enhanced dinitrogen fixation, which was mainly attributed to the cyanobacteria (Stal 2000). However, Microcoleus chthonoplastes is not capable of $\mathrm{N}_{2}$ fixation (Steppe et al. 1996, L. J. Stal pers. comm.), and $\mathrm{N}_{2}$ fixation in Microcoleus chthonoplastes mats has been attributed to consortial dinitrogen fixation by heterotrophic bacteria (Steppe et al. 1996). Several experiments have demonstrated that $\mathrm{N}_{2}$ fixation is strongly dependent on $\mathrm{N}: \mathrm{P}$ ratios (see Smith 1993 for several examples). Alternatively, a high molar $\mathrm{C}: \mathrm{N}$ ratio of organic matter may result in a $\mathrm{N}$ deficiency of heterotrophic bacteria that have typical C:N ratios of 4 to 5 (Fagerbakke et al. 1996). Hence, nitrogen limitation of heterotrophic bacteria might be a trigger for $\mathrm{N}_{2}$ fixation in these systems. A recent study, based on the use of different incubation conditions (different light qualities and inhibitors), showed that in the mats from Lake Chiprana, the induced $\mathrm{N}_{2}$ fixation was indeed not attributed to the cyanobacteria, but rather to aerobic and anaerobic heterotrophic bacteria (R. De Wit, L. Falcon, C. Charpy-Roubeaud unpubl.). In this study it was also observed that light and dark incubations did not show significant differences in $\mathrm{N}_{2}$ fixation.

\section{Chloroflexus-like organisms and relatives}

The presence of the same type of gliding green bacteria that we observed was previously reported in the Chiprana mat, although it is not permanently present (Guerrero et al. 1991, Vidondo et al. 1993). Most often Chloroflexus-type microorganisms in hypersaline microbial mats have been reported to contain Bchl $C$ (De Wit \& Caumette 1994, Nübel et al. 2001, Jonkers et al. 2003), and not Bchl $d$ as we observed in this study. However, these pigments only differ in the methylation on $\mathrm{C}-20$ for Bchl $c$. Further taxonomic work with this bacterium would hopefully provide more information on its generic assignment, but we presume that these bacteria may belong to the Chloroflexus relatives cluster recently described by Nübel et al. (2001). When the response of filamentous green bacteria to nutrient addition was studied by means of changes in Bchl $d$ concentrations, no significant changes were observed. This could mean that these bacteria are not affected by nutrient availability, and that their growth is controlled by other factors (e.g. sulphide availability in the sediments). However, the changes caused by nutrient additions in the populations of oxygenic phototrophs could also promote changes in the interaction of both anoxygenic and oxygenic phototrophs. Thus, unchanged Bchl $d$ concentrations can not only be interpreted as having no nutrient effect on the green bacteria population, but also as responses by the green bacterial population balancing the direct (increased nutrient availability) and indirect (increased competition for other factors) effects of nutrient additions on these bacteria.

\section{Chlorophyll a: pheophytin a ratios}

The ratio between chl $a$ and pheophytin $a$ was on average more than 3 -fold higher when both nutrients were added, whereas it was almost equal in the other treatments. Degradation of chlorophyll to pheophytin is indicative of cellular senescence and decline of populations. Hence, a high chl:pheophytin ratio can be 
interpreted as a signal of health in the populations of oxygenic phototrophs. We therefore assume that the combined effect of increased growth rate and a decreased degradation rate due to a balanced supply of $\mathrm{N}$ and $\mathrm{P}$ resulted in a higher accumulation of phototrophic biomass, as reflected by the increased chl a concentration. In contrast, control conditions or the addition of a single nutrient (either $\mathrm{N}$ or $\mathrm{P}$ ) yielded similarly low ratios that are indicative of a less healthy state and decreased growth among oxygenic phototrophs. Apparently, the addition of a single nutrient induced a nutrient limitation of the element that was not added.

The lower rates of gross oxygenic photosynthesis in the $\mathrm{N}$ treatments, where diatoms were differentially favoured, may suggest that the gross photosynthesis rates of diatoms are lower than those of cyanobacteria in the Chiprana mat. Alternatively, a higher development of diatoms in upper layers would decrease light availability below, where cyanobacteria are usually most abundant, so that the gross oxygenic photosynthesis by Microcoleus chthonoplastes would be restricted by the increased shading effect due to higher development of diatoms.

\section{Ecological and environmental implications}

Although our results show the response of the benthic microbial mat from Lake Chiprana in a mesocosm experiment, both the in situ effect of nutrientenhanced phytoplankton growth in the water overlying the mats and the competition with macrophytes may be important in the natural site. Because we maintained a continuous flow of sterile lake water flowing over each mesocosm, no accumulation of phytoplankton occurred in the water covering the mat. However, in natural conditions the development of phytoplankton in overlying waters would reduce the amount of light reaching the mat, especially in the deeper part of the littoral zone, perhaps inducing additional changes in the community structure and function. Our samples were, however, obtained from a shallow part of the lake where the microbial mats were covered by a less than $50 \mathrm{~cm}$ water column, and the effect of shading is, therefore, less pronounced. Furthermore, increasing shading by the overlying phytoplankton does not appear as a main factor of interference with growth of benthic phototrophic microorganisms (Marks \& Lowe 1993, Sundback et al. 1996) due to their rapid light acclimation (Falkowsky \& LaRoche 1991), at least within the photic zone. Moreover, in contrast with the higher phytoplankton growth in shallow freshwater systems associated with increased nutrient availability, saline lakes sometimes respond to an increase in nutri- ent loading by decreasing phytoplankton biomass (Robarts et al 1995, Diaz et al. 1998). In any case, our experimental design was adapted to study the influence of nutrient additions on microbial mat composition and functioning, while neglecting interactions between planktonic and benthic organisms, which is especially valid for the shallow littoral zone where microbial mats mostly developed. However, such interactions can be of paramount importance in the environment, particularly in the deeper part of the lake.

In conclusion, the relatively high availability of nitrogen, with respect to phosphorus, favoured the development of diatoms relative to cyanobacteria in the Chiprana mat. This change in community structure resulted in decreased depth-integrated gross oxygenic photosynthesis, either as a consequence of lower gross photosynthesis rates of diatoms or because of altered competitive relationships for light between diatoms and cyanobacteria, leading to lower cyanobacterial photosynthesis rates. A balanced nutrient addition promotes higher net growth rates and lower senescence of the oxygenic phototrophic community, whereas nutrient availability does not seem to have a direct effect on the population of filamentous green bacteria.

Acknowledgements. We thank Maria-Carmen Guerrero (Autonomous University of Madrid) and Alfredo Legaz (guard of COMENA, Caspe) for supplying information on the nature protection measures for Lake Chiprana, and for their efforts to raise public awareness of the originality and ecological value of the salt lakes in the Monegros region; and Helene LeCordier for her valuable help in the laboratory procedures. This work was partly supported by the European research program MICROMAT (Microbial diversity of microbial mats in Antarctica, contract $\left.\mathrm{N}^{\circ} \mathrm{BIO} 4-\mathrm{CT} 98-0400\right)$. A.C. was recipient of a grant for short-stays from the Conselleria d’Educació i Ciencia (Generalitat Valenciana).

\section{LITERATURE CITED}

Aminot A, Chaussepied M (1983) Manuel des analyses chimiques en milieu marin. CNEXO, Brest

Bebout BM, Paerl HW, Crocker KM, Prufert LE (1987) Diel interactions of oxygenic photosynthesis and $\mathrm{N}_{2}$ fixation (acetylene reduction) in a marine microbial mat community. Appl Environ Microbiol 53:2353-2362

Buffan Dubau E, Pringault O, De Wit R (2001) Artificial cold-adapted mats cultured from Antarctic lake samples. 1. Formation and structure. Aquat Microb Ecol 26: $115-125$

Castenholz RW (1976) The effect of sulfide on the bluegreen algae of hot springs. I. New Zealand and Iceland. J Phycol 12:54-68

Castenholz RW (1977) The effect of sulfide on the blue-green algae of hot springs: II Yellowstone National Park. Microb Ecol 3:79-105

Caumette P, Matheron R, Raymond N, Relexans JC (1994) Microbial mats in the hypersaline ponds of mediterranean salterns (Salins de Giraud, France). FEMS Microbiol Ecol 13:273-286 
De Wit R, Caumette P (1994) Diversity of and interactions among sulphur bacteria in microbial mats. In: Stal LJ, Caumette P (eds), Microbial mats: structure, development and environmental significance. NATO Asi Series, Series G: Ecological sciences, Vol 35. Springer-Verlag, Berlin, p 377-392

Des Marais DJ (1995) The biogeochemistry of hypersaline microbial mats. In: Jones GJ (ed), Advances in microbial ecology, Vol 14. Plenum Press, New York, p 251-274

Diaz P, Guerrero M-C, Alcorlo P, Baltanás A, Florin M, Montes C (1998) Anthropogenic perturbations to the trophic structure in a permanent hypersaline shallow lake: la Salada de Chiprana (north-eastern Spain). Int J Salt Lake Res 7:187-210

Elser JJ, Marzolf ER, Goldman CR (1990) Phosphorus and nitrogen limitation of phytoplankton growth in the freshwaters of North America: a review and critique of experimental enrichments. Can J Fish Aquat Sci 47:1468-1477

Esteve I, Martínez M, Mir J, Guerrero R (1992) Distribution, typology and structure of microbial mat communities in Spain; a preliminary study. Limnetica 8:185-196

Fagerbakke KM, Heldal M, Blackburn TH (1996) Content of carbon, nitrogen, oxygen, sulfur and phosphorus in native aquatic and cultured bacteria. Aquat Microb Ecol 10: $15-27$

Falkowski PG, LaRoche L (1991) Acclimation to spectral irradiance in algae. J Phycol 27:8-14

Fenchel T (1998) Formation of laminated cyanobacterial mats in the absence of benthic fauna. Aquat Microb Ecol 14: 235-240

Flothmann S, Werner I (1992) Experimental eutrophication on an intertidal sandflat: effects on microphytobenthos, meioand macrofauna. In: Colombo G, Ferrari I, Ceccerelli VU, Rossi R (eds) Marine eutrophication and population dynamics. Olsen \& Olsen, Fredensborg, p 93-100

Fong P, Zedler JB, Donohoe RM (1993) Nitrogen vs phosphorus limitation of algal biomass in shallow coastal lagoons. Limnol Oceanogr 38:906-923

García-Pichel F, Mechling M, Castenholz RW (1994) Diel migrations of microorganims within a benthic, hypersaline mat community. Appl Environ Microbiol 60:1500-1511

Germain H (1981) Flore des Diatomees. Boubée, Paris

Giani D, Seeler J, Giani L, Krumbein WE (1989) Microbial mats and physicochemistry in a saltern in the Bretagne (France) and in a laboratory scale saltern model. FEMS Microbiol Ecol 62:151-162

Goldman CR (1978) The use of natural phytoplankton populations in bioassays. Verh Int Verein Limnol 21:364-371

Guerrero MC, De Wit R (1992) Microbial mats in the inland saline lakes of Spain. Limnetica 8:197-204

Guerrero MC, Balsa J, Pascual M, Martínez B, Montes C (1991) Caracterización limnológica de la laguna Salada de Chiprana (Zaragoza, España) y sus comunidades de bacterias fototróficas. Limnetica 7:83-96

Hillebrand H, Sommer U (1997) Response of epilithic mycrophytobenthos of the Western Balthic Sea to in situ experiments with nutrient enrichment. Mar Ecol Prog Ser 160: $35-46$

Hillebrand H, Sommer U (1999) The nutrient stoichiometry of benthic microalgal growth: Redfield proportions are optimal. Limnol Oceanogr 44:440-446

Hillebrand H, Sommer U (2000) Effect of continuous nutrient enrichment on microalgae colonizing hard substrates. Hydrobiologia 426:185-192

Hillebrand H, Worm B, Lotze HK (2000) Marine microbenthic community structure regulated by nitrogen loading and grazing pressure. Mar Ecol Prog Ser 204:27-38
Jonkers $\mathrm{H}$, Ludwig $\mathrm{R}$, De Wit R, Pringault $\mathrm{O}$, Muyzer $\mathrm{M}$, Niemann H, Finke N, De Beer D (2003) Structural and functional analysis of a microbial mat ecosystem from a unique permanent hypersaline inland lake: 'La Salada de Chiprana' (NE Spain). FEMS Microbiol Ecol 44: 175-189

Jørgensen BB, Cohen Y, Revsbech NP (1986) Transition from anoxygenic to oxygenic photosynthesis in a Microcoleus chthonoplastes cyanobacterial mat. Appl Environ Microbiol 51:408-417

Krammer K, Lange-Bertalot H (1986) Bacillariophyceae: Naviculaceae. In: Ettl H, Gerloff J, Heynig H, Mollenhauer D (eds) Süsswasserflora von Mitteleuropa, Vol 2, Part 1. Gustav Fischer Verlag, Jena

Krammer K, Lange-Bertalot H (1988) Bacillariophyceae: Bacillariaceae, Epithemiaceae, Surirellaceae. In: Ettl H, Gerloff J, Heynig H, Mollenhauer D (eds) Süsswasserflora von Mitteleuropa, Vol 2, Part 2. Gustav Fischer Verlag, Stuttgart

Krammer K, Lange-Bertalot H (1991a) Bacillariophyceae: Centrales, Fragilariaceae, Eunotiaceae. In: Ettl H, Gerloff J, Heynig H, Mollenhauer D (eds) Süsswasserflora von Mitteleuropa, Vol 2, Part 3. Gustav Fischer Verlag, Stuttgart

Krammer K, Lange-Bertalot H (1991b) Bacillariophyceae: Achnanthaceae. In: Ettl H, Gerloff J, Heynig H, Mollenhauer D (eds) Süsswasserflora von Mitteleuropa, Vol 2, Part 4. Gustav Fischer Verlag, Stuttgart

Marks JC, Lowe RL (1993) Interactive effects of nutrient availability and light levels on the periphyton composition of a large oligotrophic lake. Can J Fish Aquat Sci 50: $1270-1278$

Nilsson P, Jönsson B, Linström Swanberg I, Sundbäck K (1991) Response of shallow-water sediment system to an increased load of inorganic nutrients. Mar Ecol Prog Ser 71:275-290

Nübel U, Bateson MM, Madigan M, Kühl M, Ward DM (2001) Diversity and distribution in hypersaline microbial mats of bacteria related to Chloroflexus spp. Appl Environ Microbiol 67:4365-4371

Paerl HW, Joye S, Fitzpatrick M (1993) Evaluation of nutrient limitation of $\mathrm{CO}_{2}$ and $\mathrm{N}_{2}$ fixation in marine microbial mats. Mar Ecol Prog Ser 101:297-306

Pinckney J, Paerl HW, Fitzpatrick M (1995a) Impacts of seasonality and nutrients on microbial mat community structure and function. Mar Ecol Prog Ser 123:207-216

Pinckney J, Paerl HW, Reid RP, Bebout B (1995b) Ecophysiology of stromatolitic microbial mats, Stocking Island, Exuma Cays, Bahamas. Microb Ecol 29:19-37

Revsbech NP, Jørgensen BB (1983) Photosynthesis of benthic microflora measured with high spatial resolution by the oxygen microprofile method: capabilities and limitations of the method. Limnol Oceanogr 28:749-756

Riegman R, Mur LR (1986) Phytoplankton growth and phosphate uptake (for P limitation) by natural phytoplankton populations from the Loosdrecht Lakes (The Netherlands). Limnol Oceanogr 31:983-988

Robarts RD, Doland D, Arts M (1995) Phytoplankton primary production of three temporary prairie wetlands. Can J Fish Aquat Sci 52:897-902

Rowan KS (1989) Photosynthetic pigments of algae. Cambridge University Press, Cambridge

Smith VH (1993) Applicability of resource-ratio theory to microbial ecology. Limnol Oceanogr 38:239-249

Sommer U (1989) Nutrient status and nutrient competition of phytoplankton in a shallow, hypertrophic lake. Limnol Oceanogr 34:1162-1173 
Stal LJ (1988) Nitrogen fixation in cyanobacterial mats. In: Packer L, Glazer AN (eds) Methods in enzymology 167, Cyanobacteria. Academic Press, San Diego, p 474-484

Stal LJ (2000) Cyanobacterial mats and stromatolites. In: Whitton BA, Potts M (eds) The ecology of cyanobacteria. Kluwer Academic Publishers, Dordrecht, p 61-120

Stal LJ, Van Gemerden H, Krumbein WE (1985) Structure and development of a benthic marine microbial mat. FEMS Microbiol Ecol 31:111-125

Steppe TF, Olson JB, Paerl HW, Litaker RW, Belnap J (1996) Consortial $\mathrm{N}_{2}$ fixation: a strategy for meeting nitrogen requirements of marine and terrestrial cyanobacterial mats. FEMS Microbiol Ecol 21:149-156

Stolz JF (1990) Distribution of phototrophic microbes in the flat laminated microbial mat at Laguna Figueroa, Baja California, Mexico. Biosystems 23:345-357

Sundbäck K, Snoeijs P (1991) Effects of nutrient enrichment on microalgal community composition in a coastal shallow-water sediment system: an experimental study. Bot Mar 34:341-358

Sundbäck K, Carlson L, Nilsson C, Jonssön B, Wulff A, Odmark S (1996) Response of benthic microbial mats to drifting green algal mats. Aquat Microb Ecol 10:195-208

Tilman D (1982) Resource competition and community structure. Princeton University Press, Princeton

Tilman D, Kiesking R, Sterner R, Kilham SS, Johnson FA (1986) Green, bluegreen and diatom algae: taxonomic difference in competitive ability for phosphorus, silicon and

Editorial responsibility: Kevin Carman,

Baton Rouge, Louisiana, USA nitrogen. Arch Hydrobiol 106:473-485

Utermöhl H (1958) Zur Vervollkommung der quantitativen Phytoplankton-methodik. Mitt Int Ver Theor Angew Limnol 9:1-38

Valero-Garces BL, Navas A, Machin J, Stevenson T, Davis B (2000) Responses of a saline lake ecosystem in a semiarid region to irrigation and climate variability - the history of Salada Chiprana, central Ebro basin, Spain. Ambio 29: 344-350

Van Gemerden H, Tughan CS, De Wit R, Herbert RA (1989) Laminated microbial ecosystems on sheltered beaches in Scapa Flow, Orkney Islands. FEMS Microbiol Ecol 62: 87-102

Vidondo B, Martínez B, Montes C, Guerrero MC (1993) Physico-chemical characteristics of a permanent Spanish hypersaline lake: la Salada de Chiprana (NE Spain). Hydrobiologia 267:113-125

Ward DM, Ferris MJ, Nold SC, Bateson MM (1998) A natural view of microbial biodiversity within hot spring cyanobacterial mat communities. Microbiol Mol Biol Rev 62: $1353-1370$

Whale GF, Walsby AE (1984) Motility of the cyanobacterium Microcoleus chthonoplastes in mud. Br Phycol J 19: $117-123$

Zimba PV (1998) The use of nutrient enrichment bioassays to test for limiting factors affecting epiphytic growth in Lake Okeechobee, Florida: confirmation of nitrogen and silica limitation. Arch Hydrobiol 141:459-468

Submitted: May 24, 2002; Accepted: February 24, 2003

Proofs received from author(s): June 18, 2003 